\title{
Ortaokul Öğrencilerinin Algıladıkları Sosyal Destek ile Motivasyon Yönelimleri Arasındaki İlişkinin Yapısal Eşitlik Modeli ile İncelenmesi
}

\author{
Yrd. Doç. Dr. Öznur TULUNAY-ATEŞ* \\ Mehmet Âkif Ersoy Üniversitesi, Eğitim Fakültesi, Eğitim Yönetimi ve Denetimi Bölümü, \\ Burdur / Türkiye
}

\section{$\ddot{O} z$}

$\mathrm{Bu}$ araştırmanın amacı, öğrencilerin algıladıkları sosyal desteğin motivasyon yönelimleri üzerindeki yordayıcı etkisinin incelenmesidir. Araştırmanın çalışma grubu Bartın'da 2013-2014 eğitim öğretim yılında 8. sınıfta öğrenim gören ve uygun örneklem yöntemiyle seçilen 561 öğrenciden oluşmaktadır. Araştırmada veri toplamak için Yıldırım (2004b) tarafından geliştirilen Algılanan Sosyal Destek Ölçeği (ASDÖ) ve Lepper, Corpus ve Iyengar (2005) tarafından geliştirilen ve Tulunay-Ateş ve Buluç (2015) tarafından Türkçeye uyarlanan Sınıfta Motivasyon Yönelimleri Ölçeği kullanılmıştır. Araştırmada elde edilen verilerin analizinde SPSS ve LISREL programlarından yararlanılmıştır. Araştırma sonuçları; öğrencilerin algıladıkları sosyal destek ile içsel ve dışsal motivasyon arasında anlamlı ilişki olduğunu ve sosyal desteğin içsel ve dışsal motivasyonu pozitif yönde yordadığını göstermiştir.

Anahtar Kelimeler: Algılanan sosyal destek; Sınıfta motivasyon yönelimi; İçsel motivasyon; Dışsal motivasyon; Öğrenciler.

\footnotetext{
* Sorumlu Yazar. Tel: +905052955358_ T-posta:oznurtulunayates@gmail.com

(C) 2016 Kalem Eğitim ve Sağlık Hizmetleri Vakfı. Bütün Hakları Saklıdır. ISSN: 2146-5606
} 


\title{
Examination of the Relationship Between The Social Support and the Motivational Orientation Perceived by Secondary School Students Using Structural Equation Model
}

\begin{abstract}
The aim of this study was to analyze the predictor effect of the social support, perceived by students, on their motivational orientation. The subjects of the study consisted of 561 students that received education in Bartin during 2013-2014 education year and selected through an applicable sampling method. The Perceived Support Scale developed by Yildirım (2004b) as well as the Scale of Motivational Orientations in the Classroom developed by Lepper, Corpus and Iyengar (2005), translated into Turkish by Tulunay-Ateş and Buluç (2015) were used in the study to gather data. SPSS and LISREL software packages were used for analysis of the obtained data. According to the results of the study; the social support perceived by the students was significantly related to the intrinsic and extrinsic motivation, and the social support positively predicts the intrinsic and extrinsic motivation.
\end{abstract}

Keywords: Perceived social support; Motivational orientation in the classroom; Intrinsic motivation; Extrinsic motivation; Students.

\section{Extended Summary}

One of the major indicators of a country's national success is the welfare and health level of its youth (Kayhan-Yardimc1, 2007). Therefore, determining the subjects, likely to have an impact on physical, mental and emotional health of future generations, and conducting protective and preventive studies accordingly, are of vital importance. Such kinds of protective and preventive studies are especially needed for adolescence period, since this is a difficult period for any individual in which several problems are encountered with difficulties in finding solutions, and several psychological, physiological and social changes are undergone. In this period during the psycho-social development of the adolescent, the motivation of the adolescent and the social support of the environment gain more importancy while tackling adolescence-related problems. Social support and motivation are interrelated 
concepts. The studies carried out on this relationship (Ahmed, Minneart, Werf and Kuyper, 2010; Atnafu, 2012; Federici and Skaalvik, 2014; Tezci, Sezer, Gürgan and Aktan, 2015; Wentzel, Battle, Russel and Looney, 2010) are generally of foreign origin with an increase in recent years.

\section{Purpose}

Previous researches refer to the central role of social factors on student motivation (Deci and Ryan, 2000). However, the present studies in Turkey on social support and motivation seem to be insufficient with a need to conduct further studies. Therefore, investigation of the impact of social support, supported by literature, on motivation through experimental studies, is of great importance. In this study, it is aimed to determine the influence of social support on motivation, also promoting the contribution of these variables in learning environments; and paving the way for new researches on the source, benefit and outcomes of motivation and social support.

\section{Method}

This study was carried out using relational survey model. Accordingly, structural equation model was used to determine the relationships between motivation and the level of perceived social support.

The study group of the research consisted of total 561 students receiving education in Province of Bartin at primary and secondary state schools in the $8^{\text {th }}$ grade level comprising 317 boys and 244 girls. The sampling of the research was specified by using stratified sampling technique. The research data was obtained using the Scale of Perceived Social Support developed by Yildirim (2004b) and the Scale of Motivational Orientation developed by Lepper, Corpus and Iyengar (2005).

\section{Results}

The findings obtained as a result of the analysis of data gathered in the research are briefly explained as below:

1. A low-profile and positive correlation between the social support perceived by the students from their families, friends and teachers, and their motivational orientation, was found after an in-depth analysis of the findings obtained from Pearson Product-Moment Correlation as an attempt to determine the relationship between the social support perceived by students and 
their motivation.

2. After an analysis of confirmative measurement model validity coefficients regarding the intrinsic and extrinsic motivational model compatibilities as two main dimensions of perceived social support and motivational orientations in the classroom, the scales are found to be valid ( $r>0.30)$. No problem was encountered within $t$ values and error variants of the scales. Additionally, a positively significant relation was found between the perceived social support, and intrinsic and extrinsic motivation. Confirmatory measurement model goodness of fit indexes were found to be high in general. Thus, the model can be assumed to be acceptable.

3. The direct and indirect relations between the social support perceived by students and motivational orientations in the classroom was examined in the study by using structural equation model. The findings as to the model indicate that the best indicator of perceived social support is; teacher $(\lambda=0.40$, $\mathrm{t}=8.78)$, intrinsic motivation is; curiosity $(\lambda=0.84, \mathrm{t}=18.80)$, and the extrinsic motivation is; dependence on teacher $(\lambda=0.97, t=5.02)$. A high profile, positive and significant relation was found between the perceived social support and extrinsic motivation $(\gamma=0.76, \mathrm{t}=4.79)$ and the intrinsic motivation $(\gamma=0.91$, $\mathrm{t}=14.60)$. Also, the intrinsic motivation $(\gamma=0.91)$ was found to be a more powerful predictor compared to the extrinsic motivation $(\gamma=0.76)$.

The findings regarding alternative fit values of the model indicate that the goodness of fit values $\left(\chi^{2}=113.94, \mathrm{sd}=24, \chi^{2} / \mathrm{sd}=3.84, \mathrm{RMSEA}=0.04\right.$, $\mathrm{CFI}=0.94, \mathrm{GFI}=0.95, \mathrm{AGFI}=0.92, \mathrm{RMR}=0.03, \mathrm{NFI}=0.92$ ) obtained as a result of the path analysis within the structural model, are generally high.

\section{Discussion and Conclusion}

In the present study, the predictor effect of the social support perceived by the secondary school students from their families, friends and teachers, on their intrinsic and extrinsic motivational orientations, is examined. The structural equation model of the study showed that the social support level perceived by the students, positively predicted the intrinsic and extrinsic motivation. Goodness of fit indexes showed that the model exhibited a sufficient level of fit index values. The findings related to the model indicate that the best indicator of the perceived social support is the teacher, the intrinsic motivation is interest, and the extrinsic motivation is dependency to teacher. 
The findings of the present study provide important information regarding the relationship between the social support perceived by students and their motivation. Results of the study put emphasis on the importance of social support perceived by students during their motivation. In other words, it suggests that an increase in the motivational orientations of students is possible through increasing the level of social support perceived by them.

With reference to the findings of the study, it can be asserted that the teachers' increasing their level of awareness on their importance in the social support perceived by their students; strengthening the support of the family and friends, use of diverse motivational techniques, teaching the lessons in an entertaining way that provokes interest, will contribute to the motivation of students.

Finally, the limitations on the research should be taken into account while interpreting the obtained findings. First limitation of the research is the selection of adolescents receiving education in the $8^{\text {th }}$ grade of secondary schools in Bartın, as the target group. Therefore, similar studies may be carried out using different universe, school types and research techniques.

\section{Giriş}

Bir ülkenin gençlerinin iyilik ve sağlık düzeyi, ulusal başarının en önemli göstergelerinden biridir (Kayhan-Yardımcı, 2007). Bu nedenle, gelecek kuşakların fiziksel, zihinsel ve ruhsal sağlığını etkileyebilecek konuların tespiti ve bunlara yönelik koruyucu, önleyici çalışmalar yapılması büyük önem taşır. Bu tür koruyucu ve önleyici çalışmalara özellikle de ergenlik döneminde fazlaca ihtiyaç duyulduğu söylenebilir. Çünkü ergenlik dönemi, bireyin hayatında sorunlarının yoğunlaştığı ve çözüm bulmakta zorlandığı, psikolojik, fizyolojik ve sosyal birçok değişimin yaşandığı zorlu bir dönemdir. $\mathrm{Bu}$ dönemde ergenin psikososyal gelişiminde, yaşadığı zorlukların üstesinden gelmesinde motivasyonu ve çevresinin sosyal desteği daha da önem kazanmaktadir.

Adams'a (1995, s.15) göre "Ergenlik yüzleşilmesi gereken temel görevler olarak; eğitim, olgunlaşma ve beklemeyi içeren bir dönemdir". Bu dönemde ergen, çocukluk yaşantısında öğrendiği kurallarla, yetişkinlikte geliştirmesi gereken değer yargıları arasında bocalamaktadır (Gençtan, 1995). 
Birçok eğitimci "Eğitim evde başlar, okulda devam eder." görüşünde birleşmektedir. Çünkü aile ilk ve etkili bir kaynaktır. Ergenlik ise, fırtınalı bir dönem olarak nitelendirilmektedir. Bu firtınalı dönemi ergenin zarar görmeden atlatabilmesinin büyük oranda, ailede kazandığı temelin sağlamlığına bağlı olduğu söylenebilir.

Temel eğitimin yaklaşık olarak 4. ve 5. sınıfını kapsayan 9-12 yaş dönemi genelde ön ergenlik olarak adlandırılmaktadır. Savi ve Akboy (2010) temel eğitimin 2. dönemi olan 6., 7. ve 8. sınıfları; çocuğun, çocukluk döneminden çıkıp ergenlik dönemine başladığı bir geçiş dönemi olarak nitelemektedir.

Yörükoğlu (1998; s.13, 38, 43-45) ergenliği içine alan 12-15 yaş arasını ilk gençlik, 15-21 yaş arasına asıl gençlik olarak adlandırmaktadır. Ortaokul dönemini kapsayan ilk gençlik döneminde öğrencilerin çoğunun; sağlık, kişilik, aile ve ev, kız-erkek arkadaşlığ 1 , meslek seçimi, din ve ahlâk ya da okulla ilgili alanlarda kaygıları olabilmektedir. Sezer (2012) ise, ilköğretim ve ortaöğretim kademesinde okuyan öğrenciler üzerinde yaptığı araştırmada, öğrencilerin problem alanlarının daha çok okul ve gelecek üzerinde yoğunlaştığını, öğrencilerin en ciddi problemlerinin okuldaki fiziksel yetersizliklerin ve kişiliklerinden kaynaklı sorunlar olduğunu saptamıştır.

Yörükoğlu (1998) ve Sezer'in (2012) ifadeleri, ergenlik dönemindeki öğrencilerin problemlerinin eğitsel, meslekî, sosyal ve duygusal alanlarda yoğunlaştığını göstermektedir. Bu nedenle de ergenlik problemlerinin çözümünün bu alanlarda yaşanan sorunların çözüme kavuşturulmasında önemli olduğu söylenebilir. Hatta, Topçu'nun insan ve toplum ile ilgili sorunların temelde bir ahlâk sorunu olduğu düşüncesinden (Gündoğan, 2006) hareketle, ergenlik dönemi ile ilgili yaşanan kişisel ve toplumsal sorunların aslında, ahlâk sorunu olduğu söylenebilir. Bu düşünce Güngör'ün (1998) gelişimle ilgili düşünceleri ile de desteklenmektedir. Güngör'e (1998) göre; bireysel gelişim alanları birbiriyle yakın ilişkilidir ve bir bütündür. Fakat gelişimsel farklılıklarının fark edilmesini ve inceleme kolaylığını sağlamak amacıyla gelişim; sosyal gelişim, duygusal gelişim, zihinsel gelişim vs. gibi alanlara ayrılmaktadır. Bununla beraber bir alandaki gelişimin öbür alanlardaki değişmelerle yakından ilgili olduğuna dikkat etmek gerekmektedir. Örneğin, ahlâkî gelişim, zihinsel ve duygusal gelişimden ayrı düşünülemez. Ahlâkî hayatımız hem duygu, hem bilgi, hem de davranış olaylarının birleşimidir. 
Millî Eğitim Bakanlığı 2014-2015 istatistiklerine göre, örgün eğitimden 17 milyon 559 bin 989 öğrenci yararlanmaktadır. Bu öğrencilerden temel eğitim kademesinde resmî okullarda eğitim gören 11 milyon 285 bin 574 öğrencinin, \%44.9'u yani 5 milyon 69 bin 683 'ü ortaokullarda bulunmaktadır. Özel okullarda eğitim gören 583 bin 344 öğrencinin ise, \%35.7'si ortaokulda bulunuyor (MEB Örgün Eğitim İstatistikleri, 2015). Verilen istatistikler incelendiğinde, Türkiye genelinde örgün eğitimden yararlanan öğrencilerin nerdeyse, 2/3'sinin temel eğitim kademesinde olduğu görülmektedir. $\mathrm{Bu}$ nedenlerle bu dönemde öğrencilerin yaşadığ problemler, motivasyon ve sosyal destek gibi konular daha kritik bir önem taşır.

\section{Algılanan Sosyal Destek}

Kuramsal temeli Kurt Lewin'in (1951) “Alan Kuramı ve Davranış Tanımı"na dayanan sosyal destek, bireyin çevresinden sağladığı sosyal ve psikolojik destek olarak tanımlanabilir. Lewin'e (1951)göre, davranış psikolojik çevrede olan değişimdir. Bu nedenle, bireyin olumsuz davranışlarını ortadan kaldırmak ve yeni davranışlar kazanmasını sağlamak, psikolojik çevresinde değişiklik yapmakla mümkün olabilir (akt; Yıldırım, 1997, 1998).

Yıldırım (2004a) sosyal desteğin, yapısal ve işlevsel destek olarak iki kategoride düşünüldüğünü belirtmektedir. Yapısal destekte bireyin kimlerden destek aldığı, destek veren kişilerin sayısı ve bireye yakınlık derecesi önemliyken işlevsel destekte verilen yardımın birey için önemlilik derecesi ve ne ifade ettiği, bireyin ihtiyacı olan desteğin ne kadarını karşıladığı söz konusudur (Yıldırım, 2004b).

Öğrencilerin gelişimlerini ve akademik başarılarını etkileyen faktörler arasında yer alan "aile", "öğretmen" ve "arkadaş" öğrenci açısından önemli sosyal destek kaynaklarındandır (Yıldırım, 1998). Ortaokul düzeyindeki ergenler üzerinde yapılan araştırmalar (Cırık, Oktay ve Fer, 2014; Elcik, 2015; Malecki ve Demaray, 2003) öğrencilere sağlanan sosyal desteğin hangi kaynaklardan (aile, öğretmen, sınıf arkadaşı ve yakın arkadaş) sağlandığına göre farklılık gösterdiği sonucuna ulaşmıştır.

Lynch ve Cicchetti (1997) 1226 düşük riskli ilk ve ortaokul öğrencisi üzerinde yaptıkları araştırmada çocuklardan alınan bilgilere göre yetişkinlerle (anne ve öğretmenler) ve akranlarla (iyi arkadaş ve sınıf arkadaşları) ilişkilerinin kalitesinde ilkokuldan ortaokula değişim olduğu sonucuna ulaşmıştır. 
Araştırmacılar, ortaokul öğrencileri ilkokul öğrencilerine göre akranlarıyla ilişkilerinde daha pozitif, yetişkinlerle ilişkilerinde daha az pozitif algıları olduğunu belirtmiştir.

Yapılan araştırmalar, öğrencilere sağlanan sosyal desteğin gelişimlerine olan katkısını farklı açılardan incelemiştir. Sosyal desteğin sağladığı katkılara örnek olarak; öfke kontrolünde başarı sağlaması, okula uyumu artırması, şiddet eğilimini ve stres düzeyini düşürmesi, depresyondan kurtulmaya yardımcı olması, fiziksel, zihinsel ve duygusal yönden sağlık hissine yardımcı olmas1 verilebilir (C1rık, Oktay ve Fer, 2014).

Sosyal desteğin bütün bireylerde iki önemli fonksiyonu; uyum ve gelişime katkıda bulunmak ve strese karşı korumaktır (Richman, Rosenfeld ve Bowen, 1998). Çocukların okul ortamı içinde ve dışında ilişkilerine bağlı yaşadığı sosyal ve duygusal süreçler okula başarılı şekilde uyum sağlamalarında önemlidir (Lynch ve Cicchetti, 1997). Zaten yapılan araştırma sonuçlarında sosyal desteğin fizyolojik ve psikolojik sağlık (Bayram, 1999; Cohen ve Wills, 1985; Thoits, 1995; Wang ve Sound, 2008), kendini iyi hissetme ve uyum süreci üzerinde önemli etkisinin olduğunu (Ökdem ve Yardımc1, 2010) ve ergenlerde, sosyal destek arttıkça uyum düzeyinin yükseldiğini, depresyon düzeyinin düştüğünü (Elmac1, 2006) göstermektedir.

Demaray ve Malecki (2002b) yaptıkları araştırmada, algılanan sosyal destek ve pozitif göstergeler (örneğin: sosyal beceriler, benlik kavramı ve uyum becerisi) arasında anlamlı pozitif ilişkiler olduğunu, problemli davranış göstergeleri (örneğin: içselleştirme ve dışsallaştırma) arasında anlamlı negatif ilişkiler olduğunu belirtmiştir.

Demeray ve Malecki (2002a) risk altındaki ergenlerde algılanan sosyal destekle uyumsuzluk arasındaki ilişkiyi inceledikleri araştırma sonuçlarında, sosyal destek ile klinik ve okul uyumsuzluğu göstergeleri arasında anlamlı ilişkiler bulmuştur. Malecki ve Demeray (2003) yaptıkları bir başka çalışmada, ailelerin destekleyici davranışları öğrencilerin okula uyumunda katkıda bulunduğu, öğretmenlerin duygusal desteğinin öğrencilerin sosyal becerilerinin ve akademik yeterliklerinin önemli belirleyicisi olduğu sonucuna ulaşmiştır.

Cohen ve Wills (1985) sosyal desteğin sağlık üstündeki yararlı etkisini 
değerlendirmek amacıyla yaptıkları çalışmada birçok araştırmanın sosyal destek ve sağlık arasındaki pozitif ilişkinin kanıtı olduğunu belirtmiştir. Araştırmacılara göre, birçok çalışma sosyal desteğin, psikolojik ve fiziksel sağlık sonuçlarının ilişkili olduğunu göstermektedir. Sosyal desteğin, ruh sağlığı sonuçları ve ciddi fiziksel hastalık sonuçları ile ilişkili olması beklenmektedir. Genel olarak pozitif sosyal ilişkilerin olmaması, kaygı ya da depresyon gibi negatif psikolojik durumlara neden olur.

Richman, Rosenfeld ve Bowen (1998) de sosyal destek ile bireyin fiziksel ve zihinsel sağlığı arasında pozitif ilişki olduğunu belirtmektedir. Yazarlar, çeşitli araştırma bulgularına dayanarak desteğin; hastalığı azaltmak, stresi azaltmak, tükenmişlikle mücadele, sağlık hissini artırma, iş performansı ve işte yeniliği artırma, yalnızlık hissini azaltma gibi amaçlarla kullanıldığını belirtmiştir.

Cohen ve Wills (1985) sosyal destek ve sağlık ilişkisini iki modelle incelemiştir. Bunlar, temel ya da doğrudan etki modeli (main-or direct-effect model) ve tampon etki modelidir (buffering model). Araştırmalarda genel olarak 4 sosyal destek türünden bahsedilmektedir. Bunlar; saygı desteği (esteem support), araçsal destek (instrumental support), bilgi desteği (informational support) ve sosyal arkadaşlıktır (social companionship). Richman, Rosenfeld ve Bowen (1998) göre ise, sosyal desteğin; maddî, bilgisel ve duygusal şeklinde üç yaygın türü vardır. Sosyal destek algısı sekiz şekilde görülebilir. Bunlar; dinleme desteği, duygusal destek, duygusal meydan okuma, gerçeği doğrulama desteği, görevi takdir desteği, göreve meydan okuma desteği, maddî yardım desteği, kişisel yardım desteğidir.

Araştırmacıların sosyal destek türleri konusunda farklı sınıflandırmaları bulunmakla birlikte, sosyal desteğin temelde; maddî, manevî, bilişsel ve sosyal olmak üzere dört boyutunun olduğu söylenebilir.

Ergenlerde, algılanan sosyal destekle çeşitli değişkenler arasındaki ilişkilerinin incelendiği birçok araştırma bulunmaktadır. Bu araştırmalardan bazılarında algılanan sosyal destekle çeşitli değişkenler arasındaki pozitif ilişkiler tespit edilmiştir. Bu araştırmalarda incelenen değişkenlere örnek olarak, benlik saygısı (Kahriman, 2002; Savi-Çakar ve Karataş, 2012), stresle başa çıkma (Demirtaş, 2007), öz yeterlik (Kayhan-Yardımcı, 2007), karar verme (Deveci, 2011; Dülger, 2009), problem çözme (Arslan, 2009; Budak, 
1999), öz duyarlık (Akkaya, 2011), psikolojik sağlamlık (Turgut, 2015), sosyal yetkinlik (Kaşı, 2009; Traş ve Arslan, 2013), ruhsal belirti (Bayram, 1999), akademik başarı (Ateş, 2012; Levitt, Guacci-Franco ve Levitt, 1994; Richman, Rosenfeld ve Bowen, 1998; Yıldırım, 1998, 2000, 2006), sosyal duygusal beceriler (Elcik, 2015) verilebilir. Alg1lanan sosyal destekle negatif ilişki içinde olduğu tespit edilen değişkenlere ise, siber zorbalığa eğilim (Peker ve Eroğlu, 2015), saldırganlık (Ustabaş, 2011), yalnızlık (Öztürk, Nazik-Sevindik ve Yaman, 2006) örnek verilebilir.

\section{Motivasyon}

Bireyin bazı hedeflerine ulaşmak, bazı beklentilerini veya ihtiyaçlarını karşılamak için kullandığı hareket ettirici güç olarak tanımlanan (Mullins, 2006) motivasyon; temelde enerji, yön ve devamlılık şeklindeki üç kavramı barındırır ve doğrudan ölçülemez. Fakat davranış değişiklikleriyle gözlenebilir (Kurt, 2010). Sosyal desteğin de motivasyonla benzer özellikte olduğu; duygu, düşünce ve davranışlara yansıdığı söylenebilir.

Motivasyon konusu esas olarak kişilerin bekleyiş ve ihtiyaçları, amaçları, davranışları, kendilerine performansları hakkında geri bildirim verilmesi konuları ile ilgilidir (Koçel, 2005). Sınıfta motivasyon ise öğrencinin duygu, düşünce, ilgi, istek ve ihtiyaçlarından etkilenen, aile, öğretmen ve arkadaşlarının tutum ve davranışlarına göre şekillenen, kısacası kendisi ve çevresiyle ilgili içsel ve dışsal birçok değişkenin rol oynadığı karmaşık bir süreçtir.

Motivasyon, öğrencinin duygu ve düşüncelerini olumlu yönde etkilemenin yanında akademik başarısına da katkı sağlar. Yapılan birçok araştırma motivasyon ve başarı arasındaki ilişkiye dikkat çekmiştir (Alşan, 2009; Aktan, 2012; Harter ve Connel, 1984; Eggen ve Kauchak, 1997; Seyis, 2011; Kurt, 2012; Lepper, Corpus ve Iyengar, 2005; Meyer, Mcclure, Walkey, Weir ve Mckenzie, 2009; Y1ldırım, 2011).

Motivasyon teorilerinde sosyal ilişki ihtiyacının önemi vurgulanmaktadır. Bu teorilere örnek olarak, Maslow'un ve Clayton Alderfer'in geliştirdiği motivasyon teorileri verilebilir. Maslow'un ihtiyaçlar hiyerarşisine göre insan ihtiyaçları; fizyolojik, güvenlik, sosyal ve aitlik, saygı ve kendini gerçekleştirme ihtiyacı şeklinde sıralanabilir (Hitt, Miller ve Colella, 2006). Clayton Alderfer'in, geliştirdiği ERG Teorisine göre ihtiyaçlar: var olma, ilişki-bağlılık ve gelişme ihtiyacı olarak üç temel sınıfa ayrılır (Graham ve 
Bennet, 1995).

İhtiyaçların karşılanması ile bireyin motivasyonu (Yazıcı, 2008) ve motivasyon kaynakları ile gelişim dönemi arasında ilişki vardır. Çocukluk döneminde motivasyon daha çok dış kaynaklı iken, ergenlik döneminde, içsel motivasyon artmaktadır. Ayrıca, hayat boyunca birey için motivasyon kaynaklarının etkililiğinin de değiştiği söylenebilir (Sarı, 2002). Motivasyon kaynaklarında yaşanan bu değişim genel olarak değerlendirildiğinde, okul öncesi döneminde çocuğun etkili motivasyon kaynağının aile, okul hayatının başlamasıyla öğretmen, ergenlik döneminde ise arkadaş olduğu söylenebilir.

Öğrencilerin erken okul yıllarında öğretmenleriyle ilişkileri sonraki akademik başarıları için zemin hazırlamada önemlidir. Erken ergenlikte öğrencilerin ebebeynleriyle ve öğretmenleriyle ilişkilerinden okul motivasyonlarını ve uyumları tahmin etmek mümkündür (Lynch ve Cicchetti, 1997).

Olumlu öğretmen-öğrenci ilişkisinin öğrenci katılımı ve motivasyonu, çaba, öğrenme stratejileri, öğrenci başarısı ve öğrenci sağlığına katkısı olduğunu öne süren ve buna güçlü kanıtlar sağlayan birçok çalışma bulunmaktadır (Federici ve Skaalvik, 2014).

Ortaokul yılları ergenin ilişki, gelişme, aitlik, kendini gerçekleştirme gibi ihtiyaçlarının ve arkadaşlarının etkisinin arttığı, içsel motivasyonun önem kazandığ bir dönem olarak nitelendirilebilir. Özellikle de, 8. sınıf artan ihtiyaç ve isteklerinin yanında sınav sonucunun hayatını şekillendireceği stresinin yaşandığı ilk ve önemli bir merhaledir. Bu nedenle, ergen bu dönemde; duygusal ve fizyolojik değişimler, okul ve meslek seçimi, kendini gerçekleştirme, sorumluluk artışı gibi faktörlerin neden olduğu kaygı ve stresle baş etmek zorunda kalmaktadır.

\section{Sosyal Destek ve Motivasyon İlişkisi}

Motivasyon ve sosyal destek kavramları incelendiğinde özellikle motivasyonun uzun bir geçmişinin olduğu görülmektedir. Motivasyon terimine ilk olarak 1880'li y1llarda İngiltere ve ABD'deki psikologların yazılarında rastlanmaktadır (Önen ve Tüzün, 2005). Sosyal destek kavramı ise son 60 yıldır yoğun bir şekilde incelenmiş ve çalışmaların odak noktasını, duygusal ya da sosyal sorunlar yaşayan ergenler oluşturmuştur (Traş ve Arslan, 2013). 
Sosyal destek ve motivasyon ilişkisi konusunda yapılan araştırmalar incelendiğinde özellikle yurt dışında yapılmış çeşitli çalışmalara rastlanmaktadır. Ahmed ve ark. (2010) sosyal ilişkilerin, motivasyonel ve duyuşsal yollar aracılığıyla dolaylı olarak akademik başarıyı etkileyebileceği fikrini destekleyen araştırmaların arttığını belirtmektedir. Federici ve Skaalvik (2014) 9. ve 10. sınıf öğrencilerin matematik derslerinde duygusal ve araçsal destek algılarının; matematik kaygısı, içsel motivasyon, yardım arama davranışı ve çabalarıyla ilişkisini araştırdığ çalışmada duygusal ve araçsal destek bütün motivasyon yapıları ile doğrudan ve dolaylı ilişkili bulunmuştur.

Kapıkıran ve Özgüngör (2009) lise öğrencileri üzerinde yaptıkları, "Ergenlerin Sosyal Destek Düzeylerinin Akademik Başarı ve Güdülenme Düzeyi ile İlişkileri”" adlı araştırmada; akademik başarının en iyi yordayıcılarının okul türü, güdülenme, kardeş sayısı ve algılanan aile desteği, güdülenmenin yordayıcılarının ise bir önceki yılın akademik ortalaması, algılanan aile desteği ve annenin eğitim düzeyi olup bu ilişkilerin lise türüne göre farkl1laştığı sonuçlarına ulaşmıştır.

Ahmed ve ark. (2010) alanyazının çoğunluğunun sosyal destek algılarının akademik başarıya katkısını göstermesine rağmen, etkinin hangi mekanizmalar aracılığıyla oluştuğu konusunda çok az çalışma bulunduğunu belirtmiştir. Araştırmacılar, yaptıkları çalışmada, 7. sınıf öğrencilerinin ebeveyn, akran ve öğretmen sosyal destekleri ile matematik başarısı arasındaki deneysel bağlantıları açıklayabilmek için motivasyonel inançların (yeterlik inançları ve öznel değer) ve duyguların (kaygı ve haz) çoklu aracılık etkilerini incelemiştir. Araştırma bulguları, sosyal ilişkilerin motivasyon ve duygusal yollar aracılığıyla başarıya etkisini destekleyerek alanyazındaki teorik varsayımlara katkıda bulunmuştur.

Atnafu'nun (2012) 10. sinıf öğrencileri üzerinde yaptığı bir araştırmada öğrencilerin dişsal motivasyonunu içsel motivasyonundan daha yüksek bulunmuştur. Kızların içsel motivasyon, dışsal motivasyon, genel motivasyon ve sosyal desteği erkeklerden anlamlı olarak az bulunmuştur. Fakat okula yabancılaşma kızlarda erkeklerden daha yüksek bulunmuştur. Okula yabanc1laşma, yüksek başarıdakilerde anlamlı ve düşük değerde, alt başarıdakilerde yüksek değerde bulunmuştur. Ayrıca bütün bağımsız değişkenler, toplu ve tek olarak matematik başarısını anlamlı olarak etkilemiş̧ir. Ayrıca, matematik başarısı üzerinde, cinsiyet, başarı düzeyi ve sosyal desteğin pozitif doğrudan 
etkisi, okula yabancılaşmanın negatif doğrudan etkisi bulunmuştur.

Wentzel ve ark. (2010) ortaokul düzeyindeki genç ergenlerle yaptıkları araştırmada öğretmenlerinin ve akranlarının çoklu sınıf desteklerinin motivasyonel çıktılarla ilgi ve sosyal amaç takibi ilişkisi incelenmiştir. Araştırma sonuçları, öğrenci motivasyonu için akran ve öğretmenlerin bağımsız hem de etkileşimli katkıları olarak kabul edilen sosyal destek için çok boyutlu ölçüm yaklaşımının yararını doğrulamıştır.

Tezci ve ark. (2015) üniversitede okuyan öğretmen adayları üzerinde yaptıkları araştırmada sosyal destek elemanları ve motivasyon stratejilerini kullanım düzeyleri arasında korelasyon olduğunu belirtmişlerdir. Çalışmada dişsal motivasyon, içsel motivasyon ve genel motivasyon değerleri ile bireyin çevresinden yeterli destek alması arasında pozitif ilişki bulunmuştur.

Araştırmalar sosyal faktörlerin öğrenci motivasyonunda merkezî rolünü göstermektedir (Deci ve Ryan, 2000). Fakat, Türkiye'de, sosyal destek ve motivasyon konusunda çalışmaların az sayıda olduğu ve yapılacak çalışmalara gereksinim duyulduğu görülmektedir. Bu nedenle, alanyazın tarafından desteklenen sosyal desteğin motivasyon üzerindeki etkisinin deneysel çalışmalar ile incelenmesi büyük önem taşır. Algılanan sosyal desteğin motivasyon üzerindeki etkisinin belirlenmesi ile bu değişkenlerin öğrenme ortamlarındaki katkısını artırmak; motivasyonun ve sosyal desteğin kaynağını, faydasını ve sonuçlarını inceleyen yeni araştırmalara öncülük etmek amaçlanmıştır.

\section{Yöntem}

\section{Araştırmanın Modeli}

$\mathrm{Bu}$ araştırma, ilişkisel tarama modeli ile yapılmıştır. İlişkisel tarama modeli gerçek bir neden-sonuç ilişkisi vermemekte, bir değişkene ilişkin elde edilen bilgilerden hareketle diğer değişken ve değişkenlerdeki durumun kestirilmesine olanak tanımaktadır (Karasar, 2006). Bu amaçla motivasyon ile algılanan sosyal destek düzeyi arasındaki ilişkileri belirlemek için yapısal eşitlik modeli kullanılmıştır. En basit anlatımla faktör analizi ve regresyonun bir uzantısı olarak tanımlanabilen yapısal eşitlik modeli açımlayıcı olmaktan çok, büyük ölçüde doğrulayıcı tekniklerden oluşur (Çokluk, Şekercioğlu ve Büyüköztürk, 2012). 


\section{Çalışma Grubu}

Araştırmanın çalışma grubunu, Bartın ilinde resmî ilkokul ve ortaokullarda öğrenim görmekte olan 8. sınıf öğrencileri arasından seçilen 317'si erkek, 244 kız olmak üzere toplamda 561 öğrenci oluşturmaktadır. Araştırmanın örneklemi tabakalı örnekleme tekniği kullanılarak belirlenmiştir. "Tabakalı örnekleme yöntemi, sınırları belirlenmiş bir evrende alt tabakalar ya da alt birim gruplarının var olduğu durumlarda kullanılır. Sosyal bilimlerde sıkça kullanılan bu örneklem yönteminde önemli olan nokta, evren içindeki alt tabakaların varlığından yola çıkarak evren üzerinde çalışmaktır." (Yıldırım ve Şimşek, 2011, s.105).

\section{Veri Toplama Araçları}

Araştırmada veriler öğrencilerin, algıladıkları sosyal destek ve motivasyon yönelimleri düzeylerini belirlemek amacıyla geliştirilen iki farklı ölçeğin uygulanmasıyla elde edilmiştir.

Algılanan Sosyal Destek Ölçeği (ASDÖ): Yıldırım tarafından geliştirilmiş üçlü likert tipi bir ölçektir. Ölçek, 2004 yılında araştırmacı tarafından yeniden revize edilmiştir. Bu hâliyle ölçekte; aile, arkadaş ve öğretmen şeklinde üç alt boyut ve toplamda 50 soru bulunmaktadır. Ölçeğin Cronbach Alfa iç tutarlılık katsayısı bütün ölçek için 0.93 ; aile boyutu için 0.94 , öğretmen boyutu için 0.93 ve arkadaş boyutu için 0.91 olarak hesaplanmıştır.

Sinıfta Motivasyon Yönelimleri Ölçeği: Lepper, Corpus ve Iyengar (2005) tarafindan öğrencilerin sınıf içi motivasyon yönelimlerini belirlemek amacryla geliştirilen ve 30 maddeden oluşan beşli likert tipi bir ölçektir. Sınıfta Motivasyon Yönelimleri Ölçeği içsel ve dışsal motivasyon olmak üzere iki ölçekten oluşmaktadır. İçsel motivasyon; meydan okuma, merak, bağımsız ustalık alt boyutlarından oluşmaktadır. Dışsal motivasyon ise; kolay iş, hoşlanılan öğretmen, öğretmen bağımlılığı alt boyutlarından oluşmaktadır. Ölçekte içsel motivasyonda 17, dişsal motivasyonda ise 13 madde bulunmaktadır. Araştırmacılar tarafından Cronbach Alfa katsayısının dışsal motivasyon için .90 , içsel motivasyon için .78 olduğu bildirilmiştir.

\section{Veri Analizi ve İşlem}

Araştırma sürecinde öncelikle ölçeği geliştiren kişilerden ve gerekli kurumlardan izin alındıktan sonra uygulamalar başlamıştır. Araştırmada random yoluyla ve gönüllülüğe dayalı olarak belirlenen 569 öğrenciye ölçekler yüzyüze uygulanmıştır. Ölçeğin uygulanmasından önce ölçekle ve 
araştırma ile ilgili bilgiler öğrencilerle paylaşılmıştır. Araştırmada toplanan veriler bilgisayar ortamına aktarıldıktan sonra; eksik veri, uç değer, normallik, doğrusallık analizleri yapılmıştır. Bu incelemeler ışığında veri setinin normalliğini etkileyeceği düşünülen 8 kişiye ait form çıkarılmıştır. Veri setinden çıkarılan formlardan sonra 561 öğrenciye ait veri setinin geçerlik ve güvenirlik değerleri yeniden incelenmiş, parametrik testler için zorunlu olan varsayımları karşılayıp karşılamadığı incelenmiştir.

Algılanan Sosyal Destek Ölçeği'nin araştırmacı tarafından Cronbach Alfa ile hesaplanan güvenirlik katsayısı .94 olarak bulunmuştur. Araştırma öncesinde yapılan incelemede Cronbach Alfa ile hesaplanan güvenirlik katsayısı ölçeğin tümü için .94, aile için .85, arkadaş için .87, öğretmen için .93 olarak bulunmuştur. Cronbach Alfa değerlerinin ise (0.80-1.00) olması nedeniyle kullanılan ölçeklerin yüksek derecede güvenilir olduğu söylenebilir.

Sinıfta motivasyon yönelimleri ölçeğinin Cronbach Alfa ile hesaplanan güvenirlik katsayısı içsel motivasyon boyutunda .90 , dışsal motivasyon boyutunda .78 olarak bulunmuştur. Ölçeğin Türkçeye uyarlanması amaciyla Tulunay-Ateş ve Buluç (2015) tarafindan yapılan çalışmada ise Cronbach Alfa değerleri; ölçeğin tümü için .85, içsel motivasyon için .88, dışsal motivasyon için .84 olarak bulunmuştur.

Ölçeğin güvenirliğini tespit etmek amacıyla yapılan iki yarı test güvenirliğinde Spearman Brown iki yarı test korelasyonu, Algılanan Sosyal Destek Ölçeği'nde aile için .77, arkadaş için .84, öğretmen için .90 olarak bulunmuştur. Sınıfta Motivasyon Yönelimleri Ölçeği’nde ise, içsel motivasyon için .87 , dişsal motivasyon için .82 olarak bulunmuştur.

Veri setinin çok değişkenli istatistikler için uygun olup olmadığını tespit etmek amaciyla yapılan incelemelerde Algılanan Sosyal Destek Düzeyi için KMO değeri (0.92), Sınıfta Motivasyon Yönelimleri için KMO değeri (0.88) olarak bulunmuştur. Bu veriler maddeler arası korelasyonların faktör analizine uygunluğunu göstermiştir. KMO değerlerinin (0.80-0.90) aralığında olması, örneklem büyüklüğü açısından faktör analizi için veri yapısının iyi olduğunu göstermektedir. Barlett küresellik testi sonuçlarına göre ise Alg1lanan Sosyal Destek Düzeyi için Barlett's $\left(\chi^{2}\right)$ katsayısının 11824.056 $(p<.005)$ olduğu, ki-kare $\left(\chi^{2}\right)$ değerinin 0.01 düzeyinde manidar olduğu, Sınıfta Motivasyon Yönelimleri Ölçeği içinse Barlett's $\left(\chi^{2}\right)$ katsayısının $4229.212(p<.005)$ olduğu, ki-kare $\left(\chi^{2}\right)$ değerinin 0.01 düzeyinde manidar 
olduğu görülmektedir. Bu sonuçlar, verilerin faktör analizine uygun olduğunu göstermektedir.

Araştırmada Algılanan Sosyal Destek Düzeyi Ölçeği için yapılan Doğrulayıcı Faktör Analizi sonucunda; uyum indeksleri ise $\left(\chi^{2}=2716.94\right.$, $\mathrm{sd}=1169, \chi^{2} / \mathrm{sd}=2.32, \quad \mathrm{RMSEA}=0.04, \mathrm{CFI}=0.96, \mathrm{GFI}=0.84, \quad$ AGFI=0.82, $\mathrm{SRMR}=0.05$, NFI=0.93) olarak bulunmuştur. Araştırmada Sınıfta Motivasyon Yönelimleri Ölçeği için yapılan Doğrulayıcı Faktör Analizi sonucunda; İçsel Motivasyon Ölçeği uyum indeksleri $\left(\chi^{2}=348.09, \mathrm{sd}=114, \chi^{2} / \mathrm{sd}=3.05\right.$, RMSEA=0.06, CFI $=1.00$, GFI $=0.98$, AGFI $=0.97$, SRMR $=0.04$, NFI=1.00) olarak, Dişsal Motivasyon Ölçeği uyum indeksleri ise $\left(\chi^{2}=235.23, \mathrm{sd}=60\right.$, $\chi^{2} / \mathrm{sd}=3.92, \mathrm{RMSEA}=0.07, \mathrm{CFI}=1.00, \mathrm{GFI}=0.95, \mathrm{AGFI}=0.93, \mathrm{SRMR}=0.06$, NFI=1.00) olarak bulunmuştur. Doğrulayıcı Faktör Analizi sonucunda elde edilen uyum değerlerinin genelde yüksek düzeyde olduğu görülmüştür.

Sürekli değişkenden elde edilen puanların normal dağılım özelliği üç yöntemle incelenebilir. Birincisi çarpıklık katsayısı, aritmetik ortalama, ortanca, mod vb. betimsel istatistiklerin kullanılması, ikincisi grafik incelemesi, üçüncüsü testlerin kullanılmasıdır. Üçüncü yöntemde üç farklı test kullanılabilir. Bunlar z-istatistiği, Shapiro-Wilks ve Kolmogorov-Smirnov'dur (Büyüköztürk, 2011, s.42). Bu araştırmada grup büyüklüğü 50'den büyük olduğu için Kolmogorov-Smirnov normallik testi yapılmış ve veri setinin normal dağılıma sahip olduğu gözlenmiştir. Ayrıca, veri setinin homojenliği ve değişkenler arasında doğrusal ilişki olup olmadığı da incelenmiş ve veri setinin parametrik analizler için gerekli olan temel koşullara sahip olduğu bulunmuştur.

Veri setinin normal dağılım gösterdiği belirlendikten sonra öğrencilerin algıladıkları sosyal destek düzeyleri ile sınıfta motivasyon yönelimleri arasındaki ilişkiler Pearson Moment Çarpım Korelasyonu ile incelenmiştir. Algılanan sosyal desteğin, içsel ve dışsal motivasyon üzerindeki yordayıcı etkisi yapısal eşitlik modeli ile incelenmiş ve bu amaçla ölçüm modeli ve örtük değişkenlerle yol analizi yapılmıştır. Yapısal eşitlik modelinde çoklu uyum indeksleri olan $\chi^{2}$, sd, $\chi^{2} / \mathrm{sd}$, RMSEA, CFI, GFI, AGFI, RMR, NFI kullanılmiştır. 


\section{Bulgular}

Araştırmada toplanan verilerin analizi sonucunda elde edilen bulgular araştırma problemlerine bağlı olarak aşağıda açıklanmıştır.

\section{Algılanan Sosyal Destek ile Motivasyon Arasındaki İlişki}

Öğrencilerin algıladıkları sosyal destek ile motivasyonları arasındaki ilişkileri belirlemek için Pearson Momentler Çarpım Korelasyonu kullanılmış ve elde edilen sonuçlar Tablo 1'de verilmiştir.

Tablo 1. Algılanan Sosyal Destek ile Motivasyon Yönelimi Arasındaki İlişkiler

\begin{tabular}{lcccccc}
\hline & \multicolumn{5}{c}{ Sinıfta Motivasyon Yönelimi } \\
\cline { 2 - 7 } & $\begin{array}{c}\text { Meydan } \\
\text { Okuma }\end{array}$ & Merak & $\begin{array}{c}\text { Bağımsız } \\
\text { Ustalık }\end{array}$ & Kolay İş & $\begin{array}{c}\text { Hoşlanılan } \\
\text { Öğretmen }\end{array}$ & $\begin{array}{c}\text { Öğretmen } \\
\text { Bağımlılı̆̆ }\end{array}$ \\
\hline Aile & .206 & .195 & .213 & .083 & .037 & .162 \\
Arkadaş & .072 & .083 & .074 & .027 & .058 & .127 \\
Öğretmen & .262 & .297 & .243 & .007 & .039 & .256 \\
\hline
\end{tabular}

Tablo 1 detaylı olarak ele alındığında, öğrencilerin aile, arkadaş ve öğretmenlerinden algıladıkları sosyal destek ile motivasyon yönelimleri arasında düşük düzeyli ve pozitif yönlü bir ilişkinin olduğu söylenebilir.

Algılanan sosyal destek ile sinıfta motivasyon yönelimleri arasında anlamlı ilişkilerin belirlenmesinden sonra, algılanan sosyal desteğin motivasyon yönelimi üzerindeki yordayıcı etkisi yapısal eşitlik modeli ile test edilmiştir. Bu amaçla ilk önce algılanan sosyal destek ve sınıfta motivasyon yönelimlerinin iki ana boyutu olan içsel ve dişsal motivasyon model uyumlarına ilişkin doğrulayıcı ölçme modeli kurulmuştur. Ölçme modeli Şekil 1'de, ölçme modeline ilişkin uyum indeksleri ise Tablo 2'de verilmiştir.

Araştırmada, algılanan sosyal destek dışsal gizil değişkeni; aile, arkadaş ve öğretmen gibi bağımsız gözlenen değişkenlerden oluşmaktadır. İçsel motivasyon içsel gizil değişkeni; meydan okuma, merak ve bağımsız ustalık, bağımlı gözlenen değişkenleri aracılığıyla ölçülmüştür. Dışsal motivasyon dışsal gizil değişkeni ise; kolay iş, hoşlanılan öğretmen, öğretmen bağımlılı̆̆ bağımlı gözlenen değişkenleri aracılığıyla ölçülmüştür. Şekil 1'deki geçerlik katsayıları incelendiğinde ölçeklerin geçerli olduğu görülmektedir $(r>0.30)$. Ölçekler t değerleri ve hata varyansları açısından incelendiğinde ölçeklerde herhangi bir probleme rastlanmamıştır. Ayrıca, algılanan sosyal destek, içsel ve dışsal motivasyon arasında pozitif yönlü anlamlı bir ilişki bulunmuştur. 


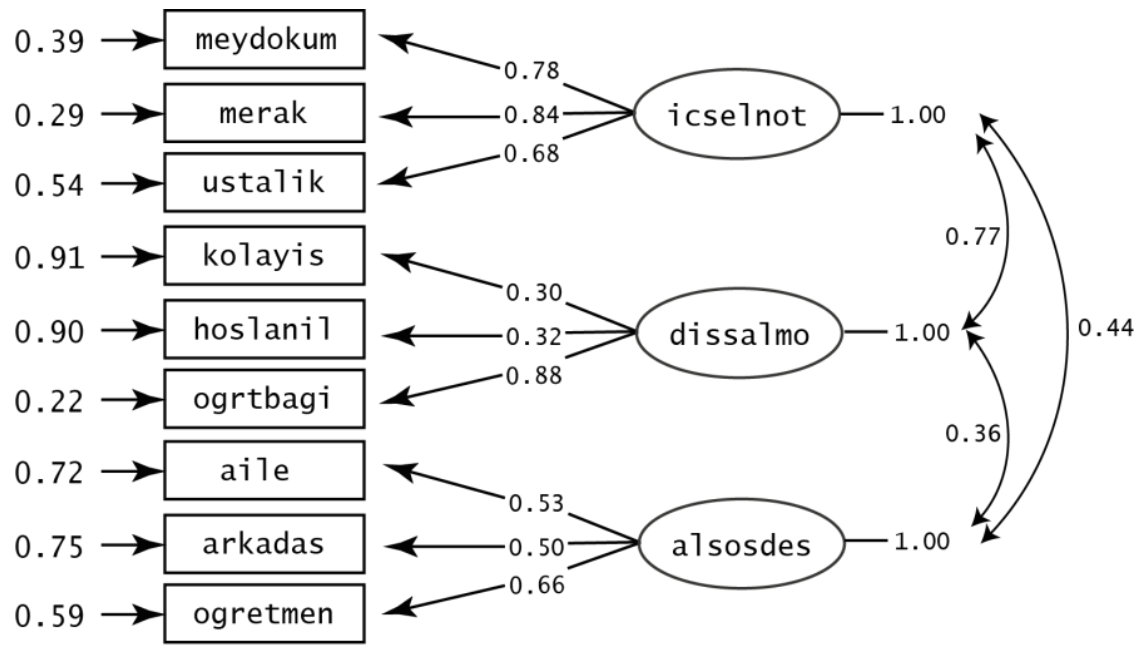

Chi-Square $=113.94, \mathrm{df}=24, \mathrm{P}-\mathrm{va} 7 \mathrm{ue}=0.00000, \mathrm{RXSEA}=0.082$

Şekil 1. Algılanan sosyal destek ile sınıfta motivasyon yönelimleri arasındaki ölçüm modeli.

Tablo 2 incelendiğinde algılanan sosyal destek ile sinıfta motivasyon yönelimleri ölçeğini oluşturan içsel ve dışsal motivasyon arasında kurulan doğrulayıcı ölçüm modeli uyum iyiliği indekslerinin genelde yüksek düzeyde olduğu görülmektedir. $\mathrm{Bu}$ nedenle modelin kabul edilebilir olduğu ifade edilebilir.

Tablo 2. Ölçüm Modeli Uyum İyiliği İndeksleri

\begin{tabular}{lccccccccc}
\hline & $\chi^{2}$ & Sd & $\chi^{2} /$ sd & RMSEA & CFI & GFI & AGFI & RMR & NFI \\
\hline Ölçüm & 113.94 & 24 & 4.74 & 0.08 & 0.94 & 0.95 & 0.91 & 0.03 & 0.92 \\
Modeli & & & & & & & & & \\
\hline
\end{tabular}

Araştırmada öğrencilerin algıladıkları sosyal destek ile sınıfta motivasyon yönelimleri arasındaki doğrudan ve dolaylı etkileri yapısal eşitlik modeli ile incelenmiştir. Modele ilişkin bulgular Şekil 2'de modelin uyum indekslerine ilişkin bulgular ise Tablo 3'de verilmiştir. 


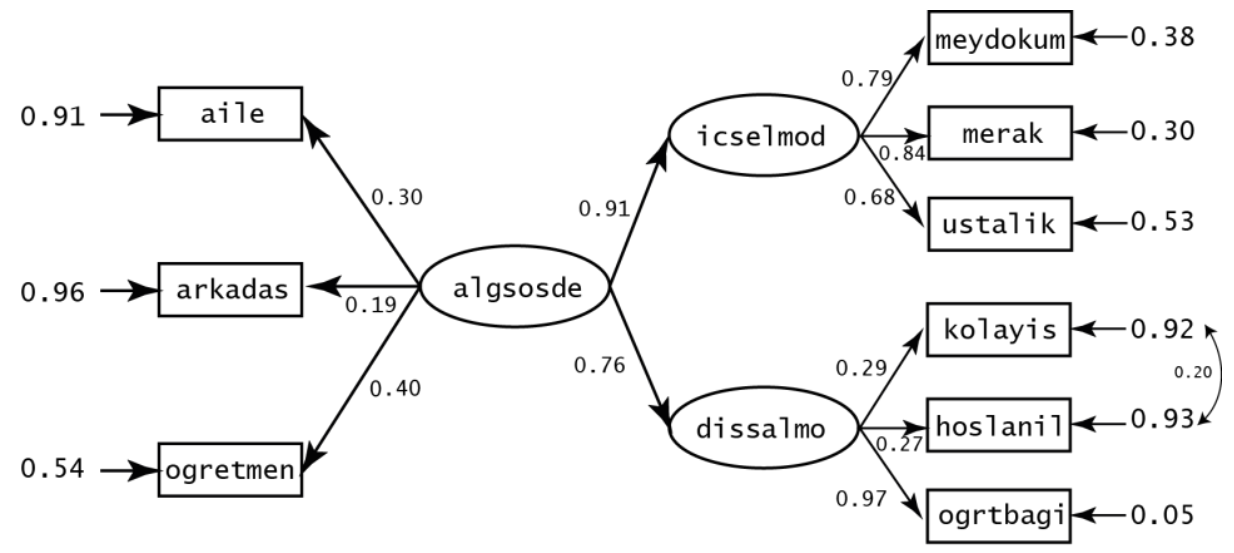

Chi-Square $=92.36, \mathrm{df}=24, \mathrm{P}-\mathrm{va}$ lue $=0.00000, \mathrm{RXSEA}=0.043$

Şekil 2. Sınıfta motivasyon yönelimleri ile algılanan sosyal destek arasındaki yapısal eşitlik modeli.

Modele ait bulgular incelendiğinde, algılanan sosyal desteğin en iyi göstergesinin; öğretmen $(\lambda=0.40, \mathrm{t}=8.78)$, içsel motivasyonun; merak $(\lambda=0.84, \mathrm{t}=18.80), \mathrm{d}$ şssal motivasyonunsa; öğretmen bağımlılığı $(\lambda=0.97$, $\mathrm{t}=5.02)$ olduğu görülmektedir. Algılanan sosyal destekle dişsal motivasyon arasında yüksek düzeyde, pozitif yönlü ve anlamlı bir ilişki bulunmuştur $(\gamma=0.76, \mathrm{t}=4.79)$. Bu değer, algılanan sosyal destekteki 1 puanlık artışın, dışsal motivasyon yöneliminde 0.76 puanlık artışa veya bunun tam tersi, algılanan sosyal destekteki 1 puanlık azalışın, dışsal motivasyon yöneliminde 0.76 puanlık azalışa neden olacağını ifade etmektedir. Algılanan sosyal destekle içsel motivasyon arasında yüksek düzeyde, pozitif yönlü ve anlamlı bir ilişki bulunmuştur $(\gamma=0.91, \mathrm{t}=14.60)$. Bu değer, algılanan sosyal destekteki 1 puanlık artışın, dışsal motivasyon yöneliminde 0.91 puanlık artışa veya bunun tam tersi, algılanan sosyal destekteki 1 puanlık azalışın, dışsal motivasyon yöneliminde 0.91 puanlık azalışa neden olacağını ifade etmektedir. Başka bir ifadeyle, öğrencilerin algıladıkları sosyal destek düzeyi azaldıkça sınıfta içsel ve dışsal motivasyonları da azalmaktadır. Ayrıca algılanan sosyal destek üzerinde içsel motivasyonun ( $\gamma=0.91)$, dişsal motivasyona $(\gamma=0.76)$ göre daha güçlü bir yordayıcı olduğu görülmektedir. İçsel motivasyonun, algılanan sosyal desteğin \%82' sini ve dişsal motivasyonun da algilanan sosyal desteğin $\% 57$ 'sini açıkladığı 0.01 anlam düzeyinde belirlenmiştir. 
Tablo 3. Araştırma Modeline İlişkin YEM Sonuçları

\begin{tabular}{|c|c|c|c|}
\hline $\begin{array}{l}\text { Latent/ } \\
\text { Gözlenen Değişkenler }\end{array}$ & $\begin{array}{c}t \\
\text { değeri* }\end{array}$ & $\begin{array}{c}\text { Standartlaştırılmış } \\
\text { Yükler }\end{array}$ & $\mathbf{R}^{2}$ \\
\hline \multicolumn{4}{|l|}{ Algllanan Sosyal Destek } \\
\hline Aile & 6.51 & 0.30 & 0.09 \\
\hline Arkadaş & 4.11 & 0.19 & 0.03 \\
\hline Öğretmen & 8.78 & 0.40 & 0.16 \\
\hline \multicolumn{4}{|l|}{ İçsel Motivasyon } \\
\hline Meydan okuma & 20.49 & 0.79 & 0.62 \\
\hline Merak & 18.80 & 0.84 & 0.70 \\
\hline Bağımsız Ustalık & 15.70 & 0.68 & 0.47 \\
\hline \multicolumn{4}{|l|}{ Dışsal Motivasyon } \\
\hline Kolay İş & 6.61 & 0.29 & 0.08 \\
\hline Hoşlanılan Öğretmen & 5.29 & 0.27 & 0.07 \\
\hline Öğretmen Bağımlılı̆̆ & 5.02 & 0.97 & 0.95 \\
\hline \multicolumn{4}{|l|}{ Yapısal İlişkiler } \\
\hline Algılanan Sosyal Destek $\rightarrow$ İçsel Motivasyon & 14.60 & 0.91 & \\
\hline Algılanan Sosyal Destek $\rightarrow$ Dışsal Motivasyon & 4.79 & 0.76 & \\
\hline \multicolumn{4}{|l|}{ Yapısal Eşitlikler } \\
\hline \multicolumn{3}{|l|}{ İçsel motivasyon $=0.91 \mathrm{x}$ algıllanan sosyal destek } & 0.82 \\
\hline \multicolumn{3}{|l|}{ Dişsal motivasyon $=0.76 \mathrm{x}$ algılanan sosyal destek } & 0.57 \\
\hline
\end{tabular}

Modelin alternatif uyum değerlerine ilişkin bulgular Tablo 4'de verilmiştir.

Tablo 4. Modelin Path Analizine İlişkin Uyum Değerleri

\begin{tabular}{lccccccccc}
\hline & $\chi^{2}$ & Sd & $\chi^{2} / \mathbf{s d}$ & RMSEA & CFI & GFI & AGFI & RMR & NFI \\
\hline $\begin{array}{l}\text { Yol } \\
\text { Analizi }\end{array}$ & 92.36 & 24 & 3.84 & 0.04 & 0.94 & 0.95 & 0.92 & 0.03 & 0.92 \\
\hline
\end{tabular}

Tablo 4 incelendiğinde yapısal modelde path analizi sonucu elde edilen uyum iyiliği değerlerinin $\left(\chi^{2}=113.94, \mathrm{sd}=24, \chi^{2} / \mathrm{sd}=3.84\right.$, RMSEA=0.04, $\mathrm{CFI}=0.94, \mathrm{GFI}=0.95, \mathrm{AGFI}=0.92, \mathrm{RMR}=0.03, \mathrm{NFI}=0.92$ ) olarak bulunmuştur. Araştırmada yapılan yol analizinde elde edilen uyum değerlerinin genelde yüksek düzeyde olduğu görülmüştür. 


\section{Tartışma ve Sonuçlar}

$\mathrm{Bu}$ araştırmada ortaokul öğrencilerinin aileden, öğretmenden ve arkadaştan algıladıkları sosyal desteğin içsel ve dışsal motivasyon yönelimleri üzerindeki yordayıcı etkisi incelenmiştir. $\mathrm{Bu}$ amaçla araştırma sürecinde algılanan sosyal desteğin içsel ve dışsal motivasyonu yordayacağı hipotezi sınanmıştır. Araştırmadan elde edilen bulgular bu hipotezin doğrulandığını ve kurulan yapısal eşitlik modelinin uyum indekslerinin yeterli düzeyde olduğunu göstermiştir.

Araştırmanın yapısal eşitlik modeli değerleri, öğrencilerin algıladıkları sosyal destek düzeyinin içsel ve dişsal motivasyonu pozitif yönde yordadığı$\mathrm{n} 1$ göstermiştir. Uyum iyiliği indeksleri ise, modelin yeterli düzeyde uyum değerlerine sahip olduğunu göstermektedir. Modele ait bulgular incelendiğinde, algılanan sosyal desteğin en iyi göstergesinin öğretmen, içsel motivasyonun merak, dışsal motivasyonun öğretmen bağımlılığı olduğu görülmektedir. Bu sonuçlar bize ortaokul öğrencileri üzerinde öğretmen sosyal desteğinin önemini göstermektedir. Fakat araştırma bulgularını değerlendirirken, örneklem grubunun 8. sınıf öğrencilerinin desteğe daha çok ihtiyaç duydukları bir dönemde olmalarının ve bu gruptaki öğrencilerin "TEOG" sınavına girmelerinin de, sonuçları etkileyebileceği göz önünde bulundurmalidir.

Araştırma bulguları; algılanan sosyal desteğin özellikle meydan okuma, merak, bağımsız ustalık ve öğretmen bağımlılığı ile yüksek düzeyli, kolay iş ve hoşlanılan öğretmenin boyutlarıyla düşük düzeyli ilişkiye sahip olduğunu göstermiştir. $\mathrm{Bu}$ bulgudan hareketle, öğrencilerin algıladıkları sosyal desteğin artması durumunda dışsal ve özellikle de içsel motivasyonun artacağı söylenebilir. Elde edilen bulgular, algılanan sosyal destek ve motivasyon arasındaki pozitif ilişkinin doğrulandığı benzer araştırmalar (Ahmed ve ark., 2010; Wentzel ve ark., 2010; Federici ve Skaalvik, 2014; Tezci ve ark., 2015) tarafindan da desteklenmektedir.

Araştırmadan elde edilen bulgular öğrencilerin algıladıkları sosyal destek ve motivasyon arasındaki ilişkiye yönelik önemli bilgiler sunmaktadır. Araştırma sonuçları öğrencilerin motivasyonlarında algıladıkları sosyal desteğin önemli rolüne dikkat çekmektedir. Başka bir ifadeyle, öğrencilerin algıladıkları sosyal destek düzeyinin artmasının, motivasyonlarını artıracağını göstermektedir. 
İnsan doğası gizli kalmış yönlerinden dolayı karmaşık olmasına rağmen, bir o kadarda sistemlidir. Çünkü, Sezgin ve Sezgin'in (2011) de ifade ettiği gibi; hayatında hem özne ve hem de nesne durumunda olan insan bilinçli bir varlıktır. Etrafındaki nesneleri ve kendisini; algılar, anlar ve anlamlandırır. Motivasyon döngüsünün de, bireyde sistemli şekilde işleyen bir süreç olduğu söylenebilir. Bu süreçte ilk olarak birey kendisine verilen desteği hisseder, böylece duygu ve düşüncelerinin değişir, bu değişimler davranışlarına yansır.

Sosyal ilişkilerin motivasyon ve duygusal yollar aracılı̆̆ıyla başarıya etkisi olduğu sonucuna ulaşan (Ahmed ve ark., 2010) öğretmen desteği ile akademik başarıdaki pozitif yönlü anlamlı ilişkiyi vurgulayan (Ateş, 2012) araştırmaların varlığı başarıyı artırmak için motivasyondan yararlanmak gerektiğini göstermektedir.

Araştırma bulgularından hareketle, öğretmenlerin öğrencilerinin alg1ladıkları sosyal destekte taşıdığı önem konusunda farkındalık kazanmasının, aile ve arkadaş desteğinin güçlendirilmesinin, farklı motivasyon tekniklerinin kullanılmasının, derslerin eğlenceli ve merak uyandırarak etkin şekilde işlenmesinin, öğrencilerin motivasyonlarına katkı sağlayacağı söylenebilir.

Sosyal destek ve motivasyon ilişkisini vurgulayan ve sosyal desteğin motivasyon üzerindeki etkisi olduğunu belirten, sosyal desteğin ve motivasyonun başarı üzerindeki etkisini gösteren, çalışmalar olmasına rağmen; ülkemizde bu alanda yeterince araştırma yapılmadığı söylenebilir. Bu nedenle, yapılan çalışma, araştırmacılar ve uygulayıcılar için önemli bilgiler verebilir.

Son olarak araştırmadan elde edilen bulguların yorumlanmasında araştırmanın sınırlılıkları da göz önünde bulundurulmalıdır. Araştırmanın birinci sınırlılı̆̆ araştırmanın hedef kitlesi olarak Bartın'da ortaokul 8. sınıfta öğrenim görmekte olan ergenlerin seçilmesidir. $\mathrm{Bu}$ nedenle benzer araştırmalar; evren, okul türleri, araştırma yöntemlerinde farklı1ıklar yapılarak gerçekleştirilebilir.

\section{Kaynakça}

Adams, J. F. (1995). Ergenliği anlamak. (B. Onur, Çev.). Ankara: İmge Kitabevi. (Orijinal çalışma basım tarihi 1995)

Ahmed, W., Minnaert, A., Van der Werf, G. ve Kuyper, H. (2010). Perceived 
social support and early adolescents' achievement: The mediational roles of motivational beliefs and emotions. Journal of Youth and Adolescence, 39, 36-46.

Akkaya, Ç. (2011). Ortaögretim ögrrencilerinde algılanan sosyal destek ve öz-duyarlık düzeyleri. Yayımlanmamış yüksek lisans tezi, Sakarya Üniversitesi, Eğitim Bilimler Enstitüsü.

Aktan, S. (2012). Öğrencilerin akademik başarısı öz düzenleme becerisi, motivasyonu ve öğretmenlerin öğretim stilleri arasındaki ilişki. Yayımlanmamış doktora tezi, Balıkesir Üniversitesi, Sosyal Bilimler Enstitüsü.

Alşan, E. U. (2009). Kimya öğretmen adaylarının akademik başarılarına öğrenme stili tercihleri, öz kontrollü ögrenme ve motivasyonun etkisi. Yayımlanmamış doktora tezi, Hacettepe Üniversitesi, Sosyal Bilimler Enstitüsü.

Arslan, Y. (2009). Lise öğrencilerinin alglladıklarl sosyal destek ile sosyal problem çözme arasindaki ilişkilerin incelenmesi. Yayımlanmamış yüksek lisans tezi, Selçuk Üniversitesi, Sosyal Bilimler Enstitüsü.

Ateş, B. (2012). Ortaöğretim öğrencilerinin sosyal destek algılarının bazı değişkenlere göre incelenmesi. Akademik Bakış Dergisi, 30(3), 1-16, http://www.akademikbakis.org

Atnafu, M. (2012). Motivation, social support, alienation from the school and their impact on students' achievement in mathematics: The case of tenth grade students. The Ethiopian Journal of Education and Science, $8(1), 53-74$.

Bayram, D. (1999). Bir grup gençte ruhsal belirti ile sosyal destek ilişkisi. Yayımlanmamış doktora tezi, Dokuz Eylül Üniversitesi, Sosyal Bilimler Enstitüsü.

Budak, B. (1999). Lise ögrencilerinde algllanan sosyal destek düzeyi ile problem çözme becerileri arasındaki ilişki. Yayımlanmamış yüksek lisans tezi, Ondokuz Mayıs Üniversitesi, Sosyal Bilimler Enstitüsü. 
Büyüköztürk, Ş. (2011). Sosyal bilimler için veri analizi el kitabı (14. bask1). Ankara: Pegem.

Cirık, İ., Oktay, A. ve Fer, S. (2014). İlköğretim öğrencilerinin algıladıkları sosyal destek düzeyleri. Eğitim ve Bilim, 39(173), 169-180.

Cohen, S. ve Wills, T. A. (1985). Stress, social support and buffering hypothesis. Psychological Bulletin, 98(2), 310-357.

Çokluk, Ö., Şekercioğlu, G. ve Büyüköztürk, Ş. (2012). Sosyal bilimler için çok değişkenli istatistik SPSS ve LISREL uygulamaları (2. baskı). Ankara: Pegem.

Deci, E. L. ve Ryan, R. M. (2000). The "what" and "why" of goal pursuits: Human needs and self-determination of behavior. Psychological Inquiry, 11(4), 227-268.

Demaray, M. K. ve Malecki, C. K. (2002a). Critical levels of perceived social support associated with student adjustment. School Psychology Quartely, 17(3), 213-241.

Demaray, M. K. ve Malecki, C. K. (2002b). The relationship between perceived social support and maladjustment for students at risk. Psychology in the School, 39(3), 305-316.

Demirtaş, A. S. (2007). İlköğretim 8. sınff öğrencilerinin algılanan sosyal destek ve yalnızlık düzeyleri ile stresle başa çıkma düzeyleri arasındaki ilişki. Yayımlanmamış yüksek lisans tezi, Gazi Üniversitesi, Eğitim Bilimleri Enstitüsü.

Deveci, F. (2011). Ergenlerde karar verme stilleri ile algllanan sosyal destek düzeyi arasındaki ilişkinin incelenmesi. Yayımlanmamış yüksek lisans tezi, Çukurova Üniversitesi, Sosyal Bilimler Enstitüsü.

Dülger, Ö. (2009). Ergenlerde algılanan sosyal destek ile karar verme davranışları arasındaki ilişkinin incelenmesi. Yayımlanmamış yüksek lisans tezi, Marmara Üniversitesi, Eğitim Bilimleri Enstitüsü.

Eggen, P. ve Kauchak, D. (1997). Educational psychology: Windows on 
classrooms (3. bask1). Singapore: Upper saddle River N. J. Merrill.

Elcik, F. (2015). Üstün yetenekli öğrencilerin çevresinden algıladıkları sosyal destek düzeyi ile sosyal duygusal becerileri arasındaki ilişki. Yayımlanmamış doktora tezi, Dumlupınar Üniversitesi, Eğitim Bilimleri Enstitüsü.

Elmac1, F. (2006). Parçalanmış ve bütünlüğünü koruyan aileye sahip ergenlerin depresyon ve uyum düzeylerinde sosyal desteğin rolü. Kuram ve Uygulamada Eğitim Bilimleri, 6(2), 403-431.

Federici, R. A. ve Skaalvik, E. M. (2014). Students' perceptions of emotional and instrumental teacher support: Relations with motivational and emotional responses. International Education Studies, 7(1), 21-36.

Gençtan, E. (1995). Psikodinamik psikiyatri ve normal dışı davranışlar (12. bask1). İstanbul: Remzi Kitabevi.

Graham, H. T. ve Bennet, R. (1995). Human resource management. England: Trans Atlantic.

Gündoğan, A. O. (2006). Topçu ve hareket felsefesi. Hece 109 (Özel Sayı: 11), 15-22,

http://www.aliosmangundogan.com/PDF/Makale/Ali-Osman-Gundog an-Nurettin-Topcu-ve-Hareket-Felsefesi.pdf

Güngör, E. (1998). Değerler psikolojisi üzerine araştırmalar. İstanbul: Ötüken Yayınları.

Harter, S. ve Connel, J. P. (1984). A model of children's achievement and related self-perceptions of compedence, control and motivational orientation. J. Nicholls, (Ed.), Advances in motivation and achievement içinde (219-250). Greenwich, CT: JAI Press.

Hitt, M. A., Miller, C. C. ve Colella, A. (2006). Organizational behavior: A strategic approach. Hoboken: John Willey \& Sons.

Kahriman, İ. (2002). Adölesanlarda aile ve arkadaştan algılanan sosyal destek ile benlik saygısı arasındaki ilişki. Yayımlanmamış yüksek li- 
sans tezi, Atatürk Üniversitesi, Sağlık Bilimleri Enstitüsü.

Kapıkıran, Ş. ve Özgüngör, S. (2009). Ergenlerin sosyal destek düzeylerinin akademik başarı ve güdülenme düzeyi ile ilişkileri. Çocuk ve Gençlik Ruh Să̆glı̆̆ Dergisi, 16(1), 21-30.

Karasar, N. (2006). Bilimsel araştırma yöntemi. Ankara: Nobel.

Kaşık, D. Z. (2009). Ergenlerde karar verme stilleri ve algilanan sosyal destek düzeylerinin sosyal yetkinlik beklentisi ve bazı değişkenler açısından incelenmesi. Yayımlanmamış yüksek lisans tezi, Selçuk Üniversitesi, Sosyal Bilimler Enstitüsü.

Kayhan-Yardımcı，F. (2007). İlköğretim öğrencilerinde algılanan sosyal destek ile öz yeterlik ilişkisi ve etkileyen değişkenlerin incelenmesi. Yayımlanmamış doktora tezi, Ege Üniversitesi Sağlık Bilimleri Enstitüsü.

Koçel, T. (2005). İşletme yöneticiliği. İstanbul: Arıkan.

Kurt, T. (2010). Okul yönetiminde insan ilişkileri (3. bask1). S. Özdemir, (Ed.), Türk Ĕgitim Sistemi ve Okul Yönetimi içinde (109-143). Ankara: Nobel.

Kurt, M. (2012). Çoklu zeka kuramına dayalı öğrenme yöntemi ve motivasyon stilleri etkileşiminin öğrencilerin tutum, akademik başarı ve bilgilerinin kalıcılığına etkisi. Yayımlanmamış doktora tezi, Atatürk Üniversitesi, Eğitim Bilimleri Enstitüsü.

Lepper, M. R., Corpus, J. H. ve Iyengar, S. S. (2005). Intrinsic and extrinsic motivational orientations in the classroom: Age differences and academic correlates. Journal of Educational Psychology, 97(2), 184-196.

Levitt, M. J., Guacci-Franco, N. ve Levitt, J. L. (1994) Social support and achievement in childhood and early adolesence: A multicultural study. Journal of Applied Developmental Psychology, 15(2), 207-222.

Lynch, M. ve Cicchetti, D. (1997). Children's relationships with adults and peers: An examination of elementary and junior high school students. 
Journal of School Psychology, 35(1), 81-99.

Malecki, C. K. ve Demaray, M. K. (2003). What type of support do they need? Investigating student adjustment as related to emotional, informational, appraisal and instrumental support. School Psychology Quarterly, $18(3), 231-252$.

Meyer, L. H., Mcclure, J., Walkey, F., Weir, K. F. ve Mckenzie, L. (2009). Secondary student motivation orientations and standarts-based achievement outcomes. British Journal of Educational Psychology, 79(2), 273-293.

Mullins, L. J. (2006). Essentials of organizational behavior. England: Financial Times Prentice Hall.

Ökdem, Ş. ve Yardımcı, F. (2010). Üniversite öğrencilerinin algılanan sosyal destek düzeylerinin bazı değişkenler açısından incelenmesi. Anatolian Journal of Psychiatry, 11, 228-234.

Önen, L. ve Tüzün, M. B. (2005). Motivasyon. İstanbul: Epsilon.

Öztürk, H., Nazik-Sevindik, F. ve Yaman, S. Ç. (2006). Öğrencilerde yalnızlik ve sosyal destek ile bunlara etki eden faktörlerin incelenmesi. Fırat Üniversitesi Sosyal Bilimler Dergisi, 16(1), 383-394.

Peker, A. ve Eroğlu, Y. (2015). Ergenlerde algilanan sosyal destek ve siber zorbalığa eğilim arasındaki ilişkiler: Arkadaştan ve öğretmenden alg1lanan sosyal desteğin arac1 rolü. Turkish Studies, 10(3), 759-778.

Richman, J. M., Rosenfeld, L. B. ve Bowen, G. L. (1998). Social support for adolescents at risk of school failure. Social Work, 43(4), 309-323.

Sarı, E. (2002). Sinıf yönetimi. Ankara: ÜBL Yayınları.

Savi, F. ve Akboy, R. (2010). Ön ergenlik dönemi davranış sorunları ile aile işlevleri arasındaki ilişkinin incelenmesi.

http://psikiyatriksosyalhizmet.com/wp-content/uploads/2010/03/on_er genlik.pdf 
Savi-Çakar, F. ve Karataş, Z. (2012). Ergenlerin benlik saygısı, algıladıkları sosyal destek ve umutsuzluk düzeyleri: Bir yapısal eşitlik modeli ça1ışması. Kuram ve Uygulamada Eğitim Bilimleri, 12(4), 2397-2412.

Seyis, S. (2011). Ortaöğretim ögrencilerinin motivasyonlart ve duygusal zekaları ile akademik başarıları arasındaki ilişsk. Yayımlanmamış yüksek lisans tezi, Karadeniz Teknik Üniversitesi, Eğitim Bilimleri Enstitüsü.

Sezer, F. (2012). Öğrencilerin problem alanlarının tespiti ve buna yönelik çözüm önerileri. TIJSEG, 2(1), 27-36.

Sezgin, O. ve Sezgin, A. S. (2011). Psiko-sosyal açıdan küreselleşme, empoze kültür ve davranışa yansıması. Kalem Eğitim ve İnsan Bilimleri Dergisi, 1(1), 91-122.

Tezci, E., Sezer, F., Gürgan, U. ve Aktan, S. (2015). A study on social support and motivation. Anthropologist, 22(2), 284-292.

Thoits, P. A. (1995). Stress, coping and social support processes: Where are we? What next?, Journal of Health and Social Behavior (Özel Say1), 53-79.

Traş, Z. ve Arslan, E. (2013). Ergenlerde sosyal yetkinliğin algılanan sosyal destek açısından incelenmesi. İlköğretim Online, 12(4), 1133-1140.

Tulunay-Ateş, Ö. ve Buluç, B. (2015). Sinıfta motivasyon ölçeği geçerlik ve güvenirlik çalışması. Uluslarası Aile Çocuk ve Ĕgitim Dergisi (ACED), 6(2), 103-124.

Turgut, Ö. (2015). Ergenlerin psikolojik sağlamlık düzeylerinin, önemli yaşam olayları, algılanan sosyal destek ve okul bağlllı̆̆ı açısından incelenmesi. Yayımlanmamış yüksek lisans tezi, Anadolu Üniversitesi, Eğitim Bilimleri Enstitüsü.

Ustabaş, S. (2011). Illköğretim 8. sinıf ögrencilerinin saldırganlık ve algılanan sosyal destek düzeylerinin bazı değişkenlere göre incelenmesi. Yayımlanmamış yüksek lisans tezi, Gazi Üniversitesi, Eğitim Bilimleri Enstitüsü. 
MEB örgün eğitim istatistikleri. (11 Nisan 2015).

http://trthaber.com/haber/egitim/meb-orgun-egitim-istatistiklerini-acik ladi-178127.html

Wang, C. D. C. ve Sound, C. C. (2008). The role of generational status, self esteem, academic self-efficacy, and perceived social support in college students'psychological well-being. Journal of College Counseling Association, 11,101-118.

Wentzel, K. R., Battle, A., Russell, S. L. ve Looney, L. B. (2010). Social supports from teachers and peers as predictors of academic and social motivation. Contemporary Educational Psychology, 35(3), 193-202.

Yazıc1, H. (2008). Motivasyon. Y. Özbay ve S. Erkan, (Ed.), Eğitim psikolojisi (1. bask1) içinde (423-449). Ankara: Pegem Akademi Yayıncılık.

Yıldırım, İ. (1997). Algılanan sosyal destek düzeyinin geliştirilmesi güvenirliği ve geçerliği, Hacettepe Üniversitesi Ĕ̆itim Fakültesi Dergisi, 13, 81-87.

Yıldırım, İ. (1998). Akademik başarı düzeyleri farklı olan lise öğrencilerinin sosyal destek düzeyleri. Türk Psikolojik Danışma ve Rehberlik Dergisi, 2(9), 33-38.

Yıldırım, İ. (2000). Akademik başarının yordayıcısı olarak yalnızlık, sınav kaygısı ve sosyal destek. Hacettepe Üniversitesi, Eğitim Fakültesi Dergisi, 18, 167-176.

Yıldırım, İ. (2004a). Eş destek ölçeğinin geliştirilmesi. Psikolojik Danışma ve Rehberlik Dergisi, 22(3), 19-26.

Yıldırım, İ. (2004b). Algılanan sosyal destek ölçeğinin revizyonu. Eğitim Araştırmalart-Eurasian Journal of Educational Research, 17, 221-236.

Yıldırım, İ. (2006). Akademik başarının yordayıcısı olarak gündelik sıkıntılar ve sosyal destek, H.Ü. Eğitim Fakültesi Dergisi, 30, 258-267.

Yıldırım, S. (2011). Öz-yeterlik, içe yönelik motivasyon, kaygı ve matematik başarısı: Türkiye, Japonya ve Finlandiya'dan bulgular. Necatibey Ĕgi- 
tim Fakültesi Elektronik Fen ve Matematik Eğitimi Dergisi (EFMED), 5(1), 277-291.

Yıldırım, A. ve Şimşek, H. (2011). Sosyal bilimlerde nitel araştırma yöntemleri (8. baskı). Ankara: Seçkin.

Yörükoğlu, A. (1998). Gençlik çağl (10. baskı). İstanbul: Özgür Yayınları. 